\title{
PENGARUH MODEL PROBLEM BASED-LEARNING DENGAN FLIPPED CLASSROOM TERHADAP KEMAMPUAN BERPIKIR KREATIF
}

\author{
Sinta Ayu Damayanti, I Wayan Santyasa, dan A. A. I. A. Rai Sudiatmika \\ Fakultas Matematika dan Ilmu Pengetahuan Alam Universitas Pendidikan Ganesha \\ email: ayusintadamayanti24@gmail.com
}

\begin{abstract}
Abstrak
Penelitian ini bertujuan untuk mendeskripsikan perbedaan kemampuan berpikir kreatif fisika siswa yang belajar dengan model pembelajaran problem-based learning dengan flipped classroom (PBLFC), model pembelajaran tradisonal dengan flipped classroom (PTFC), dan model pembelajaran tradisional dengan direct instruction (DI). Jenis penelitian ini adalah eksperimen semu (quasi-experiment) dengan desain one way pretest-posttest non-equivalent control group design. Sampel terdiri 86 siswa SMA yang terbagi dalam 3 kelas. Kelas eksperimen 1 menerapkan PBLFC, kelas eksperimen 2 dengan PTFC dan kelas kontrol dengan pembelajaran DI. Data kemampuan berpikir kreatif dikumpulkan dengan 15 butir soal esai dengan materi usaha dan energi, serta momentum dan impuls. Data yang terkumpul dianalisis dengan analisis deskriptif dan ANAKOVA. Hasil penelitian ini mengungkapkan adanya perbedaan yang signifikan pada kemampuan berpikir kreatif fisika antara siswa yang belajar dengan PBLFC, PTFC, dan DI. Hasil Uji BNt (Beda Nyata terkecil) menunjukkan bahwa kemampuan berpikir kreatif fisika siswa yang belajar dengan PBLFC lebih tinggi dibandingkan dengan PTFC dan DI. Pembelajaran aktif dengan flipped classroom perlu dikembangkan dalam pembelajaran fisika untuk mendorong kemampuan berpikir kreatif siswa.
\end{abstract}

Kata kunci: problem based learning, flipped classroom, kemampuan berfikir kreatif

\section{THE EFFECT OF PROBLEM-BASED LEARNING FLIPPED CLASSROOM TOWARDS PHYSICS CREATIVE-THINKING ABILITY}

\begin{abstract}
This study was aimed at describing the differences in the creative-thinking abilities of the students who learn physics using the problem-based learning model with flipped classroom (PBLFC), traditional learning model with flipped classroom (TLFC), and traditional learning models with direct instruction (TLDI). A quasi-experimental with a one-way pretestposttest non-equivalent control group design was used in this study. The sample consisted of 86 high school students divided into 3 classes. The experimental class 1 implemented PBLFC, experimental class 2 implemented TLFC, and the control class implemented TLDI learning. The data on the ability to think creatively were collected using 15 essay item tests with material on effort and energy, and momentum and impulses. The data then were analyzed by descriptive analysis and ANACOVA. The results of this study show that there are significant differences in the ability to think creatively between physics students who study with PBLFC, TLFC, and TLDI. Least Significant Difference (LSD) test results show that the creative thinking abilities of students who learn physics with PBLFC are higher than those with TLFC and TLDI. Active learning with flipped classroom needs to be developed in physics learning to encourage students' creative-thinking abilities.
\end{abstract}

Keywords: problem-based learning, flipped classroom model, creative thinking 


\section{PENDAHULUAN}

Partnership for $21^{\text {st }}$ Century Learning mengembangkan sebuah framework pembelajaran yang menuntut siswa untuk memiliki keterampilan, pengetahuan dan kemampuan di bidang teknologi, media, dan informasi. Framewok pembelajaran abad 21 ini meliputi critical thinking, comunication, collaboration skills, and creative thinking (Hidayah, Salimi, \& Susiani, 2017). Siswa seharusnya memiliki keterampilan berpikir kritis dan kreatif, kemampuan literasi, menguasai teknologi informasi, serta terampil berkomunikasi untuk memenuhi tuntutan pembelajaran di abad 21. Keterampilan-keterampilan tersebut mendorong terbentuknya sumber daya manusia (SDM) yang berkualitas, terutama dalam mengembangkan dan menggunakan kemampuan berpikir kreatif.

Berpikir kreatif sangat penting dikembangkan untuk membantu memecahkan permasalahan, dan mencari alternatif pemecahan masalah. Berpikir kreatif ini akan menjadi bekal utnuk menghadapi permasalahan yang ada terutama dalam era globalisasi ini. Pentingnya pengembangan berpikir kreatif juga dituangkan di dalam tujuan pendidikan nasional yaitu mengembangkan potensi siswa agar menjadi manusia yang bertakwa kepada Tuhan Yang Maha Esa, berakhlak mulia, sehat, berilmu, cakap, kreatif, mandiri, dan menjadi warga negara yang demokratif serta bertanggung jawab. Pemberdayaan berpikir kreatif pada proses pembelajaran di sekolah akan menginternalkan watak ataupun kecenderungan siswa untuk dapat berpikir kreatif (UU Sisdiknas Nomor 20 Tahun 2003).

Pembelajaran fisika memerlukan banyak keterampilan dasar dan kemampuan berpikir untuk memecahkan masalah. Pembelajaran fisika seharusnya dilakukan dengan pendekatan ilmiah. Siswa tidak hanya dituntut untuk memperoleh nilai yang bagus akantetapi juga harus mampu menerapkan kemampuan berpikir tingkat tinggi seperti berpikir kreatif yang dibutuhkan dalam menemukan konsepkonsep fisika. Kemampuan berpikir kreatif merupakan kemampuan menerapkan berbagai pengetahuan dan keterampilan untuk menghasilkan ide-ide baru dan kemampuan mengevaluasi, menguraikan, dan memilih ide (Triyono, Senam, Jumadi, $\&$ Wilujeng, 2017). Sesuai dengan kerangka Kurikulum 2013, tujuan pembelajaran fisika adalah menguasai konsep, prinsip, dan mempunyai keterampilan untuk mengembangkan pengetahuan dan sikap percaya diri sebagai bekal untuk melanjutkan pendidikan pada jenjang yang lebih tinggi serta mengembangkan ilmu pengetahuan dan teknologi (Wakil Menteri Pendidikan dan Kebudayaan, 2014). Pembelajaran fisika yang menerapkan Kurikulum 2013 memberikan kesempatan kepada siswa untuk mengembangkan kemampuan berpikir kreatif. Berkenaan dengan penerapan Kurikulum 2013 dalam pembelajaran fisika, seyogyanya mampu mengoptimalkan kemampuan berpikir kreatif siswa.

Kenyataannya, kemampuan berpikir kreatif di Indonesia masih rendah. Berdasarkan penelitian Reynawati dan Purnomo (2018) menunjukkan bahwa skor rata-rata kemampuan berpikir kreatif siswa sebesar 28,53 dengan kategori kurang kreatif. Berdasarkan penelitian Rizal, Amrita, dan Darsono (2018) menunjukkan bahwa siswa belum mampu melatih kemampuan berpikir tingkat tinggi mereka. Selanjutnya penelitian Sirait et al. (2018) menyatakan bahwa hasil tes kemampuan berpikir kreatif siswa kurang optimal, siswa hanya dapat menjawab dengan memberikan satu solusi sehingga jika dilihat dari dimensi kemampuan berpikir kreatif untuk dimensi 
kelancaran, fleksibilitas, dan orisinalitas masih kurang.

Hasil kedua survei dan beberapa penelitian tersebut menimbulkan kesenjangan antara harapan dengan kenyataan. Kesenjangan ini disebabkan pemilihan model pembelajaran yang diterapkan masih kurang tepat. Model pembelajaran yang masih diterapkan pada saat ini yaitu model pembelajaran konvensional. Proses pembelajaran dengan menerapkan model pembelajaran konvensional cenderung berjalan satu arah yaitu dari guru ke siswa. Berdasarkan penelitian Reynawati dan Purnomo (2018) penyebab dari masalah rendahnya kemampuan berpikir kreatif siswa adalah guru pada umumnya belum melaksanakan pembelajaran yang menekankan pada proses kemampuan berpikir terutama berpikir kreatif. Selain itu guru masih menggunakan model pembelajaran tradisional yang masih bersifat teacher centered. Hal senada juga diungkapkan oleh Rizal et al. (2018) penyebab dari rendahnya kemampuan berpikir tingkat tinggi siswa dikarenakan model pembelajaran yang diterapkan oleh guru masih bersifat konvensional. Model pembelajaran konvensional ini belum mampu mengembangkan secara optimal kemampuan HOTS siswa. Hal yang sama juga diungkapkan oleh Sirait et al. (2018) penyebab rendahnya hasil tes kemampuan berpikir kreatif siswa salah duanya adalah gaya belajar dan model pembelajaran yang diterapkan oleh guru di sekolah. Model pembelajaran konvensional ini seringkali didominasi oleh guru sehingga siswa hanya menerima informasi yang diperlukan untuk menghafal. Penyebab rendahnya kemampuan berpikir kreatif siswa adalah model pembelajaran yang diterapkan di sekolah cenderung gurunya menggunakan model pembelajaran konvensional (Septiana \& Ikhsan, 2017) dan pembelajaran masih berpusat pada guru sehingga guru lebih aktif daripada siswa pada saat proses pembelajaran berlangsung (Sihaloho, Sahyar, \& Ginting, 2017).

Gagasan baru dalam pemilihan model untuk pembelajaran fisika yang diterapkan di sekolah perlu dilakukan agar kemampuan berpikir kreatif siswa optimal. Salah satu model yang dapat meningkatkan kemampuan berpikir kreatif fisika yaitu model problem-based learning yang dikombinasikan dengan model flipped classroom yang selanjutnya disebut sebagai PBLFC. Model flipped classroom adalah model pembelajaran dengan sistem belajar di rumah kemudian mendiskusikan materi di kelas. Model ini lebih menekankan bagaimana memanfaatkan waktu di kelas agar pembelajaran menjadi bermutu dan dapat meningkatkan pemahaman siswa. Selain itu, strategi memanfaatkan teknologi pada model flipped classroom mendukung materi pelajaran tambahan bagi siswa yang dapat diakses melalui media online maupun offline.

Model pembelajaran flipped classroom yang digunakan dalam penelitian ini yaitu model PBLFC. Pada tipe model ini, siswa mengeksplorasi masalah dan belajar melalui proses. Guru memberikan permasalahan, kemudian siswa jawaban atas permasalahan tersebut melalui berbagai sumber. Pada model PBLFC ini, siswa mendiskusikan pemecahan permasalahan yang telah disediakan oleh guru dengan teman sejawatnya. Sebelum diberikan permasalahan, guru sudah mengunggah terlebih dahulu video pembelajaran dengan materi yang akan dibahas di dalam kelas. Di dalam kelas, siswa bisa langsung berdiskusi dengan teman sejawatnya terkait permasalahan yang diberikan dan dapat menemukan penyelesaian permasalahan tersebut melalui sumber belajar yang berupa video pembelajaran yang telah 
diberikan oleh guru. Dengan demikian, model ini dapat merangsang siswa untuk belajar menemukan konsep yang digunakan untuk memecahkan masalah. Model problem-based learning memiliki karakteristik yaitu pembelajaran berpusat pada siswa, menggunakan masalahmasalah kontekstual, mengaktifkan keikutsertaan siswa dalam pengalaman belajar, membentuk siswa menjadi pemikir fleksibel dalam pemecahan masalah (Djidu \& Jailani, 2018).

Berdasarkan hal tersebut, model PBLFC ini diharapkan dapat meningkatkan kemampuan berpikir kreatif siswa. Berdasarkan penelitian Reynawati dan Purnomo (2018) menyatakan bahwa model pembelajaran berbasis masalah mampu mengembangkan kemampuan bernalar dalam berpikir analisis induktif dan deduktif dalam menggunakan konsep dan prinsip IPA. Model problem-based learning adalah salah satu alternatif untuk melatih kemampuan berpikir kreatif siswa. Selanjutnya penelitian Cakiroglu dan Ozturk (2017) menyatakan bahwa model PBLFC merupakan kegiatan pembelajaran berbasis masalah yang dilakukan di kelas terbalik. Model ini mampu untuk mengembangkan keterampilan dalam pemecahan masalah, kreativitas, dan produktivitas. Siswa dilatih untuk berpikir kritis, kreatif, belajar mandiri, belajar otentik dan pengembangan keterampilan dalam berkelompok. Model PBLFC merupakan model gabungan yang memanfaatkan teknologi pembelajaran dan mendukung pembelajaran yang otentik (Chis, Moldovan, Murphy, Pathak, \& Muntean, 2018).

Bukti secara empiris yang mendukung mengenai dampak positif model PBLFC terhadap kemampuan berpikir kreatif, diberikan oleh beberapa hasil penelitian, yaitu penelitian Reynawati dan Purnomo (2018) mengungkapkan bahwa terdapat perbedaan secara signifikan kemampuan berpikir kreatif siswa setelah diterapkan model problem-based learning. Cakiroglu dan Ozturk (2017) menyatakan meningkatnya kemampuan siswa dengan menerapkan model PBLFC dibandingkan dengan menggunakan model pembelajaran konvensional. Model PBLFC mampu meningkatkan kemampuan berpikir siswa dengan berbantuan video pembelajaran (Chis et al., 2018). Berkaitan dengan hal tersebut, maka dipandang perlu mengoptimalkan kualitas pembelajaran fisika dengan model PBLFC diyakini dapat meningkatkan kemampuan berpikir kreatif fisika siswa.

\section{METODE}

Penelitian ini didesain sebagai eksperimen semu (quasi experiment research). Desain yang digunakan dalam penelitian eksperimen semu ini adalah one way pretest-posttest non-equivalent control group design. Pada penelitian ini melibatkan dua variabel, yaitu variabel bebas dan variabel terikat. Variabel bebas penelitian ini adalah model pembelajaran, sedangkan variabel terikat dalam penelitian ini adalah kemampuan berpikir kreatif siswa.

Populasi dalam penelitian ini adalah seluruh siswa di SMA Negeri 1 Penebel yang menerapkan kurikulum 2013 pada Semester 2 Tahun Ajaran 2018/2019 yang terdistribusi ke dalam 4 kelas yaitu X MIPA 1, X MIPA 2, X MIPA 3, dan X MIPA 4. Semua kelas dalam populasi tersebut terdistribusi homogen secara akademik. Jumlah populasi yaitu 116 siswa.

Pemilihan sampel dalam penelitian ini menggunakan teknik pembagian acak. Pemilihan sampel dalam penelitian ini tidak langsung dilakukan pengacakan individu dalam populasi dikarenakan individu dalam populasi sudah terdistribusi ke dalam 
masing-masing kelas. Peneliti memilih 3 kelas sebagai sampel dari 4 kelas yang ada. Tiga kelas yang terpilih diundi kembali untuk menentukan perlakuan yang akan diberikan kepada masing-masing kelas. Kelas eksperimen pertama mendapatkan perlakuan pembelajaran PBLFC, kelas eksperimen kedua mendapatkan perlakuan pembelajaran tradisional dengan flipped classroom (PTFC), dan kelas kontrol mendapat perlakuan pembelajaran tradisional dengan direct instruction (DI).

Data yang dikumpulkan daam penelitian ini meliputi kemampuan berpikir kreatif fisika awal siswa berupa skor-skor pretest dan kemampuan berpikir kreatif fisika siswa berupa skor-skor posttest. Tek-nik pengumpulan data yang digunakan dalam penelitian ini berupa tes esai yang terdiri dari 15 butir soal dengan materi usaha dan energi, serta momentum dan impuls. Rentang skor setiap butir soal adalah 0-4.

Instrumen yang digunakan dalam penelitian adalah tes kemampuan berpikir kreatif yang berjumlah 15 butir, dengan konsistensi internal butir bergerak dari $\gamma=0,388 \mathrm{~s} / \mathrm{d} \gamma=0,772$ dan reliabilitas tes adalah $\alpha=0,897$ dengan klasifikasi sangat tinggi. Nilai tersebut menunjukkan bahwa tes yag digunakan reliabel untuk mengukur kemampuan berpikir kreatif.

Teknik analisis data dalam penelitian ini menggunakan analisis kovarian (ANAKOVA) satu jalur dan telah melalui uji asumsi yaitu uji normalitas, uji homogenitas, dan uji linearitas. Sebagai tindak lanjut uji ANKOVA dilakukan ujia signifikansi nilai rata-rata antarkelompok yang menggunakan Least Significant Deference (LSD).

\section{HASIL PENELITIAN DAN PEMBAHASAN}

Deskripsi umum kemampuan berpikir kreatif fisika memaparkan tentang distribusi frekuensi, nilai rata-rata, dan standar deviasi siswa untuk masing-masing kelompok perlakuan yaitu pembelajaran dengan menggunakan model PBLFC, pembelajaran dengan menggunakan model PTFC, dan pembelajaran dengan menggunakan model DI. Jumlah anggota sampel setiap perlakuan adalah berbeda, total anggota sampel dari ketiga kelompok perlakuan adalah 86 siswa. Data kemampuan berpikir kreatif fisika ini terdiri dari 15 soal esai dengan skor maksimum setiap butir tesnya yaitu 4 dan skor minimumnya yaitu 0 sehingga total skor maksimum ideal dari tes kemampuan berpikir kreatif adalah 60 dan total skor minimumnya adalah 0 .

Nilai kemampuan berpikir kreatif fisika yang dianalisis secara deskriptif diperoleh dari konversi skor kemampuan berpikir kreatif ke dalam skala 100 dengan cara membandingkan skor yang diperoleh setiap siswa terhadap skor maksimum kemampuan berpikir kreatif dan dikalikan dengan 100.

Nilai rata-rata dan standar deviasi kemampuan berpikir kreatif fisika awal siswa (pretest) untuk kelompok PBLFC,

Tabel 1

Nilai Rata-Rata dan Standar Deviasi Pretest Siswa

\begin{tabular}{lcccc}
\hline \multicolumn{1}{c}{ Kelas } & $\begin{array}{c}\text { Metode } \\
\text { Pembelajaran }\end{array}$ & $\begin{array}{c}\text { Jml } \\
\text { Siswa }\end{array}$ & $\begin{array}{c}\text { Nilai } \\
\text { Rata-rata }\end{array}$ & $\begin{array}{c}\text { Standar } \\
\text { Deviasi }\end{array}$ \\
\hline Eksperimen 1 & PBLFC & 30 & 13,67 & 5,09 \\
Eksperimen 2 & PTFC & 30 & 13,39 & 5,76 \\
Kontrol & DI & 26 & 11,41 & 4,64 \\
\hline
\end{tabular}


PTFC, dan PK disajikan pada Tabel 1. Tabel 1 menunjukkan bahwa nilai rata-rata kemampuan berpikir kreatif fisika awal siswa (pretest) pada kelompok PBLFC adalah 13,67 yang berada pada kategori sangat rendah dengan standar deviasi $=$ 5,09 . Nilai rata-rata kemampuan berpikir kreatif fisika awal siswa (pretest) pada kelompok PTFC adalah 13,39 yang berada pada kategori sangat rendah dengan standar deviasi $=5,76$. berada pada kategori sangat rendah. Nilai rata-rata kemampuan berpikir kreatif fisika awal siswa (pretest) pada kelompok DI adalah 11,41 yang dengan standar deviasi $=4,64$. Nilai rata-rata kemampuan berpikir kreatif fisika awal siswa (pretest) pada kelompok PBLFC relatif lebih tinggi dibandingkan dengan kelompok PTFC dan kelompok DI.

Nilai rata-rata kemampuan berpikir kreatif siswa setiap dimensi untuk kelompok PBLFC, PTFC, dan DI disajikan pada Tabel 2. Tabel 2 menunjukkan bahwa pada kelompok PBLFC nilai rata-rata untuk masing-masing dimensi kemampuan berpikir kreatif awal siswa lebih besar daripada nilai rata-rata pada kelompok PTFC dan DI. Dimensi berpikir lancar merupakan dimensi yang pencapaian nilainya paling tinggi yaitu 29,38 pada kelompok PBLFC, 23,13 pada kelompok PTFC, dan 22,84 pada kelompok DI. Sesuai dengan Tabel 2, maka grafik nilai rata-rata setiap dimensi kemampuan berpikir kreatif awal siswa untuk masing-masing kelompok perlakuan disajikan pada Gambar 1.

Tabel 2

Nilai Rata-Rata untuk Masing-Masing Dimensi Kemampuan Berpikir Kreatif Awal Siswa

\begin{tabular}{|c|c|c|c|c|c|}
\hline \multirow[b]{2}{*}{ Kelompok } & \multicolumn{4}{|c|}{ Rata-Rata Dimensi KBK } & \multirow{2}{*}{$\begin{array}{c}\text { Rata-Rata } \\
\text { Total }\end{array}$} \\
\hline & $\begin{array}{c}\text { Berpikir } \\
\text { Lancar }\end{array}$ & $\begin{array}{c}\text { Berpikir } \\
\text { Luwes }\end{array}$ & $\begin{array}{c}\text { Berpikir } \\
\text { Orisinalitas }\end{array}$ & $\begin{array}{l}\text { Berpikir } \\
\text { Elaborasi }\end{array}$ & \\
\hline PBLFC & 29,38 & 9,72 & 10,83 & 3,75 & 53,68 \\
\hline PTFC & 23,13 & 12,50 & 13,33 & 4,38 & 53,33 \\
\hline DI & 22,84 & 8,65 & 9,13 & 4,33 & 44,95 \\
\hline
\end{tabular}

Gambar 1. Grafik Perbandingan Nilai Pretest dan Posttest untuk Masing-masing Kelompok

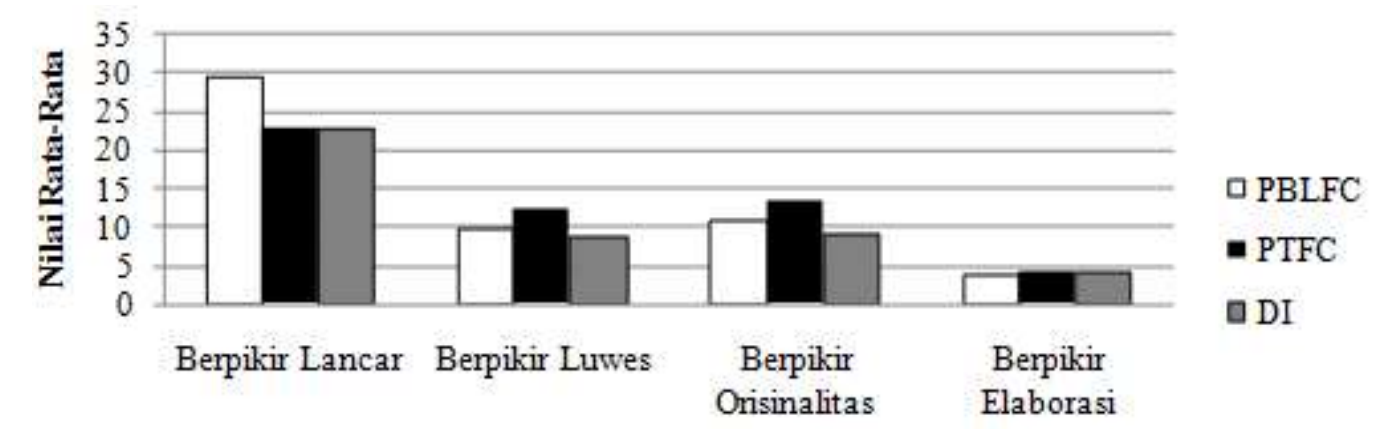

Dimensi Berpikir Kreatif 
Nilai rata-rata dan standar deviasi kemampuan berpikir kreatif fisika awal siswa (pretest) untuk kelompok PBLFC, PTFC, dan DI disajikan pada Tabel 3. Tabel 3 menunjukkan bahwa nilai rata-rata kemampuan berpikir kreatif fisika siswa (posttest) pada kelompok PBLFC adalah 67,28 yang berada pada kategori cukup dengan standar deviasi $=7,27$. Nilai ratarata kemampuan berpikir kreatif fisika siswa (posttest) pada kelompok PTFC adalah 61,00 yang berada pada kategori cukup dengan standar deviasi=5,13. Nilai rata-rata kemampuan berpikir kreatif fisika siswa (posttest) pada kelompok DI adalah 49,49 yang berada pada kategori rendah dengan standar deviasi $=8,65$. Berdasarkan Tabel 3 terlihat bahwa adanya perbedaan nilai rata-rata kemampuan berpikir kreatif fisika siswa (posttest) pada kelompok PBLFC relatif lebih tinggi dibandingkan dengan kelompok PTFC dan kelompok DI.

Peningkatan nilai rata-rata kemampuan berpikir kreatif pada kelompok PBLFC sebesar 53,61, pada kelompok PTFC sebesar 47,61, dan pada kelompok DI sebesar 38,08. Secara grafik, perbandingan antara kelompok PBLFC, PTFC, dan DI dapat dilihat dari perolehan nilai rata-rata kemampuan berpikir kreatif fisika awal siswa dan kemampuan berpikir kreatif fisika siswa yang seperti pada Gambar 2 .

Nilai rata-rata kemampuan berpikir kreatif siswa setiap dimensi untuk kelompok PBLFC, PTFC, dan DI disajikan pada Tabel 4. Tabel 4 menunjukkan bahwa pada kelompok PBLFC nilai rata-rata untuk masing-masing dimensi kemampuan berpikir kreatif lebih besar daripada nilai rata-rata pada kelompok PTFC dan DI. Dimensi berpikir orisinalitas merupakan

Tabel 3

Nilai Rata-Rata dan Standar Deviasi Posttest Siswa

\begin{tabular}{ccccc}
\hline Kelas & $\begin{array}{c}\text { Metode } \\
\text { Pembelajaran }\end{array}$ & $\begin{array}{c}\text { Jml } \\
\text { Siswa }\end{array}$ & $\begin{array}{c}\text { Nilai } \\
\text { Rata-rata }\end{array}$ & $\begin{array}{c}\text { Standar } \\
\text { Deviasi }\end{array}$ \\
\hline X MIA 1 & PBLFC & 30 & 67,28 & 7,27 \\
X MIA 4 & PTFC & 30 & 61,00 & 5,13 \\
X MIA 2 & DI & 26 & 49,49 & 8,65 \\
\hline
\end{tabular}

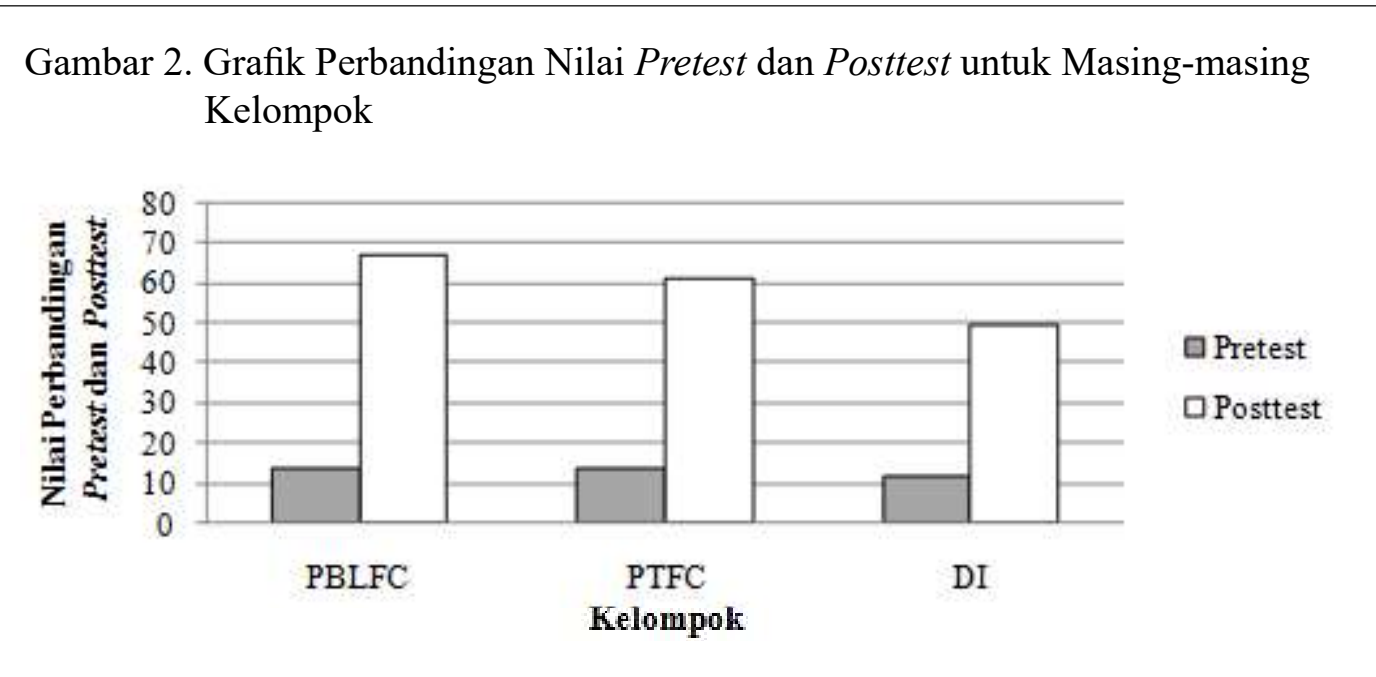


Tabel 4

Skor Rata-Rata untuk Masing-masing Dimensi Kemampuan Berpikir Kreatif Siswa

\begin{tabular}{|c|c|c|c|c|c|}
\hline \multirow[b]{2}{*}{ Kelompok } & \multicolumn{4}{|c|}{ Rata-Rata Dimensi KBK } & \multirow[b]{2}{*}{$\begin{array}{c}\text { Rata-Rata } \\
\text { Total }\end{array}$} \\
\hline & $\begin{array}{l}\text { Berpikir } \\
\text { Lancar }\end{array}$ & $\begin{array}{c}\text { Berpikir } \\
\text { Luwes }\end{array}$ & $\begin{array}{c}\text { Berpikir } \\
\text { Orisinalitas }\end{array}$ & $\begin{array}{l}\text { Berpikir } \\
\text { Elaborasi }\end{array}$ & \\
\hline PBLFC & 71,88 & 65,83 & 81,88 & 49,17 & 268,75 \\
\hline PTFC & 59,58 & 58,89 & 81,88 & 43,13 & 243,47 \\
\hline DI & 53,37 & 51,60 & 68,03 & 25,48 & 198,48 \\
\hline
\end{tabular}

dimensi yang pencapaian nilainya paling tinggi yaitu 81,88 pada kelompok PBLFC dan PTFC dan 68,03 pada kelompok DI. Hal ini menggambarkan bahwa PBLFC mampu mengoptimalkan kemampuan berpikir kreatif terutama pada dimensi berpikir orisinalitas.

Dimensi berpikir orisinalitas merupakan kemampuan berpikir siswa untuk menemukan penyelesaian baru setelah mendengarkan gagasan-gagasan baru. Hal ini berkaitan dengan sintaks dari model PBLFC yaitu pada sintaks menyempurnakan permasalahan yang telah didefinisikan dan menyimpulkan alternatifalternatif pemecahan secara kolaboratif yang mampu mengoptimalkan dimensidimensi berpikir kreatif, terutama pada dimensi orisinalitas.

Pada sintaks ini kemampuan berpikir orisinal dikembangkan dalam menyelesaikan masalah yang diberikan dengan penyelesaian yang baru berdasarkan pemahaman terhadap materi yang diperoleh melalui video pembelajaran. Selain itu, pada sintaks menyempurnakan permasalahan yang telah didefinisikan, siswa dituntut untuk menyempurnakan kembali perumusan masalah dengan merefleksikannya melalui gambaran nyata yang mereka telah pahami melalui video pembelajaran. Sedangkan pada sintaks menyimpulkan alternatifalternatif pemecahan secara kolaboratif, siswa mendiskusikan data dan informasi yang relevan dengan permasalahan. Setiap anggota kelompok mulai bergelut untuk mendiskusikan permasalahan dari berbagai sudut pandang. Kolaborasi pada tahap ini menjadi mediasi untuk menghimpun sejumlah alternatif pemecahan masalah yang menghasilkan alternatif yang lebih baik daripada melakukannya secara individual.

Sesuai dengan Tabel 4, maka grafik nilai rata-rata setiap dimensi kemampuan berpikir kreatif siswa untuk masing-masing kelompok perlakuan disajikan pada Gambar 3. Hipotesis yang diuji dalam penelitian ini yaitu terdapat perbedaan kemampuan berpikir kreatif fisika antara siswa yang belajar dengan model PBLFC, PTFC, dan model pembelajaran konvensional (DI).

Data penelitian telah diperoleh dari hasil pretest dan posttest. Data dianalisis menggunakan bantuan SPSS 25 for Windows. Uji asumsi pertama yaitu uji normalitas data menggunakan Kolmogorov-Smirnov Test. Ringkasan hasil uji normalitas ditunjukkan pada Tabel 5. Tabel 5 menunjukkan bahwa data hasil penelitian terdistribusi normal (sig. $>0,05$ ). Uji asumsi kedua yaitu uji homogenitas menggunakan Levene's Test of Equality Variance.

Ringkasan hasil uji homogenitas ditunjukkan pada Tabel 6. Tabel 6 menunjukkan bahwa varian antar kelompok adalah homogen (sig.>0,05). Uji asumsi ketiga yaitu uji linearitas antara skor pretest dan skor posttest kemampuan berpikir kreatif fisika dari ketiga kelompok. 
Gambar 3. Grafik Skor Rata-Rata untuk Masing-masing Dimensi Kemampuan Berpikir Kreatif Siswa untuk Masing-Masing Kelompok

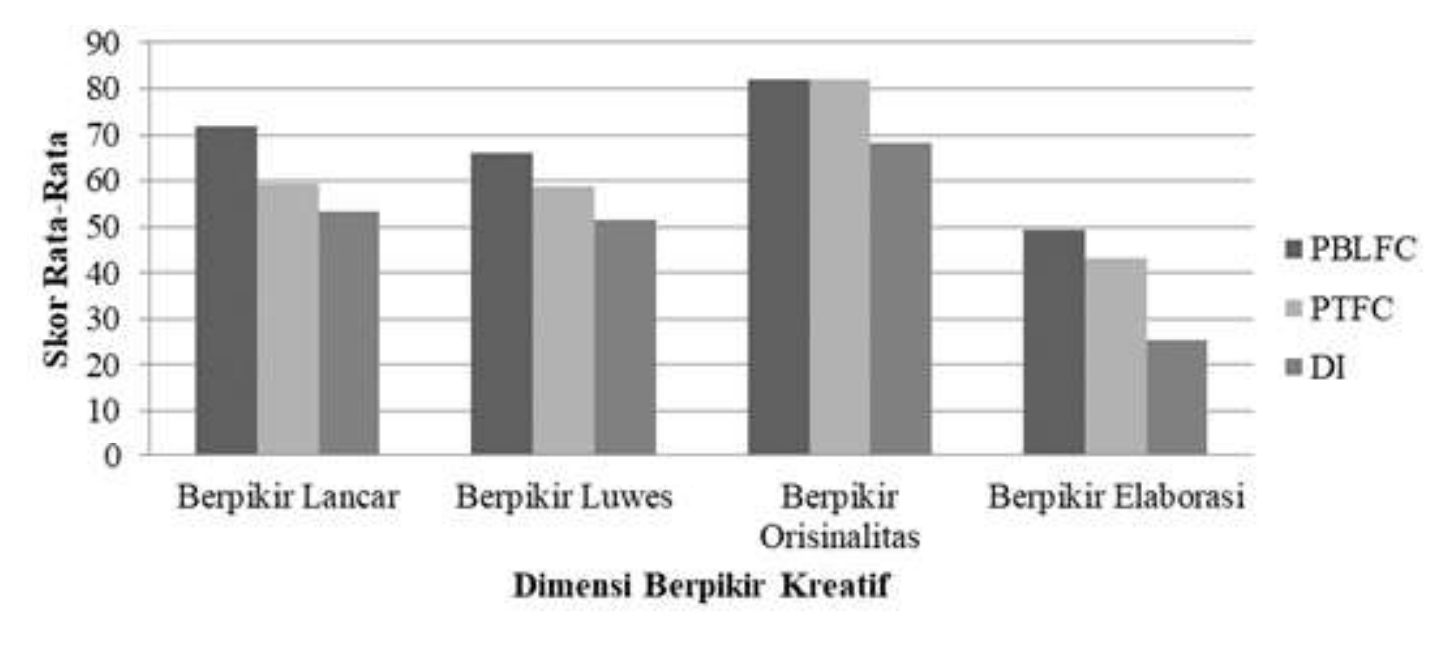

Tabel 5

Ringkasan Hasil Pengujian Normalitas Data

\begin{tabular}{ccccc}
\hline \multirow{2}{*}{ Unit Analysis } & \multicolumn{3}{c}{ Kolmogorov-Smirnov } \\
\cline { 3 - 5 } Pretest & PBLFC & 0,140 & 30 & 0,136 \\
& PTFC & 0,123 & 30 & 0,200 \\
\multirow{5}{*}{ Posttest } & DI & 0,120 & 26 & 0,200 \\
& PBLFC & 0,133 & 30 & 0,184 \\
& PTFC & 0,156 & 30 & 0,060 \\
& DI & 0,103 & 26 & 0,200 \\
\hline
\end{tabular}

Tabel 6

Ringkasan Hasil Pengujian Homogenitas Varian Antarkelompok

\begin{tabular}{lllllc}
\hline & & $\begin{array}{c}\text { Levene } \\
\text { Statistic }\end{array}$ & df1 & df2 & Sig. \\
\hline Pretest & Based on Mean & 0,219 & 2 & 83 & 0,804 \\
& Based on Median & 0,191 & 2 & 83 & 0,827 \\
& Based on Median and with adjusted df & 0,191 & 2 & 78,921 & 0,827 \\
& Based on trimmed mean & 0,225 & 2 & 83 & 0,799 \\
Posttest & 2,908 & 2 & 83 & 0,060 \\
& Based on Mean & 2,771 & 2 & 83 & 0,068 \\
& Based on Median & 2,771 & 2 & 74,988 & 0,069 \\
& Based on Median and with adjusted df & 2,862 & 2 & 83 & 0,063 \\
\hline
\end{tabular}


Ringkasan hasil uji linearitas ditunjukkan pada Tabel 7. Tabel 7 menunjukkan bahwa data hasil penelitian ketiga kelompok bersifat linier (sig linearity $<0,05$ dan sig deviation from linearity $>0,05$ ).

Hasil dari ANAKOVA kemampuan berpikir kreatif siswa berdasarakan perbedaan model pembelajaran yang diberikan ditunjukkan pada Tabel 8 . Tabel 8 menunjukkan bahwa pertama, pengaruh kemampuan berpikir kreatif fisika awal siswa terhadap kemampuan berpikir kreatif fisika siswa menunjukkan nilai statistik $\mathrm{F}^{*}=13,725$ dengan nilai signifikansi 0,001 . Hal ini menunjukkan bahwa nilai signifikansinya lebih kecil dari 0,05 , yang berarti bahwa terdapat pengaruh signifikan antara kovariat kemampuan berpikir kreatif fisika awal dengan kemampuan berpikir kreatif. Kedua, pengaruh variabel bebas terhadap variabel terikat (kemampuan berpikir kreatif fisika siswa) diperoleh nilai statistik $\mathrm{F}^{*}=43,289$ dengan angka signifikansi 0,001. Jadi, variabel terikat dalam penelitian ini yaitu kemampuan berpikir kreatif fisika siswa secara signifikan $\alpha<0,05$ dipengaruhi oleh model pembelajaran yang digunakan dalam kegiatan pembelajaran.. Ketiga, nilai $\mathrm{R}$ squared yang diperoleh berdasarkan hasil analisis adalah $\mathrm{R}^{2}=0,587$ yang mengindikasikan bahwa besarnya kontribusi model pembelajaran terhadap perbedaan kemampuan berpikir kreatif fisika siswa antara ketiga kelompok adalah 0,587 atau $58,7 \%$.

Tindak lanjut dari analisis kovarian yaitu analisis signifikansi perbedaan nilai

Tabel 7

Ringkasan Hasil Uji Linearitas

\begin{tabular}{|c|c|c|c|c|c|c|c|}
\hline Unit Analysis & & Criteria & $\begin{array}{l}\text { Sum of } \\
\text { Squares }\end{array}$ & $d f$ & $\begin{array}{l}\text { Mean } \\
\text { Square }\end{array}$ & $F$ & Sig. \\
\hline \multirow[t]{5}{*}{ Posttest*Pretest } & \multirow{5}{*}{$\begin{array}{c}\text { Between } \\
\text { Groups }\end{array}$} & (Combined) & 2221,688 & 13 & 170,899 & 1,912 & 0,043 \\
\hline & & Linearity & 1310,801 & 1 & 1310,801 & \multirow{4}{*}{$\begin{array}{l}14,666 \\
0,849\end{array}$} & \multirow{4}{*}{$\begin{array}{l}0,000 \\
0,600\end{array}$} \\
\hline & & $\begin{array}{l}\text { Deviation from } \\
\text { Linearity }\end{array}$ & 910,888 & 12 & 75,907 & & \\
\hline & & ithin Groups & 6435,034 & 72 & \multirow[t]{2}{*}{89,375} & & \\
\hline & & Total & 8656,723 & 85 & & & \\
\hline
\end{tabular}

Tabel 8

Ringkasan Hasil ANAKOVA untuk Pengujian Hipotesis

\begin{tabular}{lccccc}
\hline \multicolumn{1}{c}{ Source } & $\begin{array}{c}\text { Type III Sum } \\
\text { of Squares }\end{array}$ & $d f$ & Mean Square & $F$ & Sig. \\
\hline Corrected Model & $5083,490^{\mathrm{a}}$ & 3 & 1694,497 & 38,886 & 0,000 \\
Intercept & 32751,659 & 1 & 32751,659 & 751,598 & 0,000 \\
Pretest & 598,087 & 1 & 598,087 & 13,725 & 0,000 \\
Model & 3772,689 & 2 & 1886,344 & 43,289 & 0,000 \\
Error & 3573,233 & 82 & 43,576 & & \\
Total & 315266,378 & 86 & & & \\
Corrected Total & 8656,723 & 85 & & & \\
\hline
\end{tabular}

Keterangan: $a$. $R$ Squared $=0,587$ (Adjusted $R$ Squared $=0,572$ ) 
rata-rata kemampuan berpikir kreatif fisika siswa antara kelompok siswa yang menggunakan model PBLFC, model PTFC, dan model DI melalui LSD (Least Significant Difference).

Nilai rata-rata terestimasi dan standar deviasi kemampuan berpikir kreatif fisika siswa pada masing-masing kelompok disajikan pada Tabel 9. Tabel 9 memaparkan signifikansi nilai rata-rata kemampuan berpikir kreatif fisika siswa antara kelompok PBLFC, PTFC, dan DI yang telah dianalisis dengan metode LSD (Least Significant Difference). Ringkasan hasil uji signifikansi perbedaan nilai ratarata kemampuan berpikir kreatif fisika siswa pada kelompok PBLFC, PTFC, dan DI disajikan pada Tabel 10.

Tabel 10 menunjukkan bahwa perbedaan nilai rata-rata kemampuan berpikir kreatif fisika antara kelompok PBLFC dengan PTFC yaitu $\Delta \mu=\mu(I)-\mu(J)=6,135$ dengan standar deviasi 1,705 dan signifikansi sebesar 0,001. Angka signifikansi yang diperoleh lebih kecil dari 0,05 ; sedangkan nilai $\Delta \mu$ lebih besar dari nilai LSD. Berdasarkan perhitungan nilai LSD diperoleh sebesar 4,250. Hal ini berarti terdapat perbedaan nilai rata-rata kemampuan berpikir kreatif fisika siswa antara kelompok PBLFC dengan PTFC. Selanjutnya, perbedaan nilai rata-rata kemampuan berpikir kreatif fisika antara kelompok kreatif fisika antara kelompok PBLFC dengan DI yaitu $\Delta \mu=\mu(I)-\mu(J)=16,629 ;$ d e n g a n standar deviasi 1,796 dan signifikansi sebesar 0,001. Angka signifikansi yang diperoleh lebih kecil dari 0,05; sedangkan nilai $\Delta \mu$ lebih besar dari nilai LSD. Hal ini berarti terdapat perbedaan nilai rata-rata kemampuan berpikir kreatif fisika siswa antara kelompok PBLFC dengan DI. Perbedaan nilai rata-rata kemampuan berpikir kreatif fisika

Tabel 9

Nilai Rata-Rata Terestimasi dan Standar Deviasi Prestasi Belajar Fisika Kelompok PBLFC, PTFC, dan DI

\begin{tabular}{lcccc}
\hline \multirow{2}{*}{ Metode } & \multirow{2}{*}{ Mean } & \multirow{2}{*}{ Std. Error } & \multicolumn{2}{c}{$95 \%$ Confidence Interval } \\
\cline { 4 - 5 } & & 1,210 & 64,740 & 69,284 \\
PBLFC & 66,877 & 1,207 & 58,340 & 63,143 \\
PTFC & 60,742 & 1,311 & 47,641 & 52,856 \\
DI & 50,248 & &
\end{tabular}

Tabel 10

Hasil Signifikansi Perbedaan Nilai Rata-Rata Kemampuan Berpikir Kreatif Fisika Siswa antara Kelompok PBLFC, PTFC, dan DI

\begin{tabular}{ccccc}
\hline (I) Metode & $(J)$ Metode & $\begin{array}{c}\text { Mean Difference } \\
(I-J)\end{array}$ & Std. Error & Sig. \\
\hline PBLFC & PTFC & 6,135 & 1,705 & 0,001 \\
& DI & 16,629 & 1,796 & 0,000 \\
PTFC & PBLFC & $-6,135$ & 1,705 & 0,001 \\
& DI & 10,494 & 1,790 & 0,000 \\
\multirow{2}{*}{ DI } & PBLFC & $-16,629$ & 1,796 & 0,000 \\
& PTFC & $-10,494$ & 1,790 & 0,000 \\
\hline
\end{tabular}


antara kelompok PTFC dengan DI yaitu $\Delta \mu=\mu(I)-\mu(J)=10,494 ;$ d engan standar deviasi 1,790 dan signifikansi sebesar 0,001. Angka signifikansi yang diperoleh lebih kecil dari 0,05; sedangkan nilai $\Delta \mu$ lebih besar dari nilai LSD. Hal ini berarti terdapat perbedaan nilai ratarata kemampuan berpikir kreatif fisika siswa antara kelompok PTFC dengan DI. Kemampuan berpikir kreatif fisika yang dicapai oleh siswa yang belajar dengan PBLFC lebih tinggi dibandingkan dengan siswa yang belajar dengan PTFC dan DI. Hal ini menunjukkan bawah kemampuan berpikir kreatif siswa setelah mengikuti pembelajaran dengan menggunakan PBLFC relatif lebih baik dibandingkan dengan PTFC dan DI.

Hasil analisis deskriptif mendeskripsikan perbedaan nilai rata-rata kemampuan berpikir kreatif fisika awal siswa antara kelompok PBLFC, PTFC, dan DI. Secara umum, nilai rata-rata hasil kemampuan berpikir kreatif fisika awal siswa (pretest) pada kelompok siswa yang belajar dengan PBLFC lebih tinggi dibandingkan dengan kelompok siswa yang belajar dengan PTFC dan DI. Namun, nilai rata-rata kemampuan berpikir kreatif fisika awal siswa masih tergolong sangat rendah.

Rendahnya nilai rata-rata kemampuan berpikir kreatif fisika awal siswa dipengaruhi oleh berbagai macam faktor baik faktor internal siswa maupun faktor eksternal siswa. Selain itu rendahnya kemampuan berpikir kreatif fisika awal siswa juga disebabkan oleh siswa yang belum pernah mempelajari materi usaha dan energi serta momentum dan impuls pada jenjang pendidikan sebelumnya (SMP) ataupun semester sebelumnya. Hal tersebut menyebabkan secara umum siswa belum mengetahui tentang materi usaha dan energi serta momentum dan impuls sebelum diberikan perlakuan.
Setelah diberikan perlakuan terhadap ketiga kelompok tersebut hasilnya terlihat bahwa ada perbedaan antara nilai rata-rata kemampuan berpikir kreatif fisika siswa antara ketiga kelompok, dimana kelompok PBLFC memperoleh nilai rata-rata lebih tinggi dibandingkan dengan kelompok PTFC dan DI.

Berdasarkan hasil analisis kovarian pada penelitian ini menunjukkan beberapa hal sebagai beriku. Pertama, terdapat pengaruh yang signifikan $(\alpha<0,05)$ antara variabel kovariat kemampuan berpikir kreatif awal siswa terhadap kemampuan berpikir kreatif siswa. Hasil ini menunjukkan bahwa kemampuan berpikir kreatif siswa dipengaruhi secara signifikan oleh variabel kovariat. Pengaruh variabel kovariat yang signifikan ini tereliminasi dengan menggunakan ANAKOVA sehingga hubungan antarkemampuan berpikir kreatif pada penelitian ini tidak terganggu oleh variabel bebas.

Kedua, terdapat perbedaan kemampuan berpikir kreatif antara siswa yang belajar dengan model PBLFC, model PTFC, dan model DI. Ketiga, kemampuan berpikir kreatif siswa yang mengikuti pembelajaran dengan model PBLFC secara signifikan lebih tinggi dibandingkan dengan siswa yang mengikuti pembelajaran dengan model PTFC maupun model DI.

Keempat, hasil tindak lanjut uji LSD menunjukkan bahwa kemampuan berpikir kreatif fisika siswa yang belajar dengan PBLFC lebih baik diterapkan dibandingkan dengan PTFC dan DI. Maka dengan demikian pengaruh PBLFC terhadap kemampuan berpikir kreatif fisika secara statistik lebih unggul dibandingkan dengan pengaruh PTFC dan DI terhadap kemampuan berpikir kreatif fisika.

PBLFC dan PTFC merupakan model yang sama-sama menggunakan model flipped classroom. Akan tetapi, PBLFC 
dipadukan dengan model problem-based learning sedangkan PTFC dipadukan dengan model pembelajaran traditional learning. Model problem-based learning ini merupakan model yang dirancang untuk membantu siswa dalam mengembangkan kemampuan berpikir kreatif, memecahkan masalah, dan menjadikan siswa pembelajar mandiri. Selain itu, siswa juga dapat mencari konsep yang dipelajari dengan memanfaatkan sumber dan media baik cetak maupun online.

Mengacu pada nilai kriteria ketuntasan minimum (KKM) di SMA Negeri 1 Penebel sebesar 70,00; maka nilai rata-rata kemampuan berpikir kreatif fisika pada kelas yang menerapkan PBLFC dan PTFC belum mencapai nilai kriteria ketuntasan minimum (KKM). Hal ini di-akibatkan oleh kemampuan berpikir kreatif memerlukan waktu yang relatif lama dan harus dilakukan secara kontinu untuk dapat mengoptimalkan kemampuan berpikir kreatif siswa.

Penelitian yang dilakukan oleh Geminiawan (2018, p. 98) menemukan bahwa kemampuan berpikir kreatif siswa yang diperoleh setelah diberikan perlakuan masih berkategori kurang. Hal ini disebabkan oleh kemampuan berpikir kreatif setiap siswa berbeda-beda secara alami (faktor internal) sehingga tidak seluruh siswa dapat meningkatkan kemampuan berpikir keatif secara optimal dalam waktu yang realtif singkat.

Penelitian yang dilakukan oleh Hasanah, Darmawan, dan Nanang (2019) mengungkapkan bahwa peningkatan kemampuan berpikir kreatif siswa pada kelas eksperimen dalam kategori sedang. Hal ini disebabkan oleh tidak adanya latihan secara kontinu yang dilakukan oleh siswa untuk menguasai keempat dimensi dari berpikir kreatif dan keterbatasan waktu yang menyebabkan tidak ada pemantauan terhadap kemampuan berpikir kreatif siswa ketika siswa telah selesai mengerjakan tugas maka siswa sudah dianggap menguasai keempat dimensi dari kemampuan berpikir kreatif.

Temuan penelitian oleh Trianggo dan Yuanita (2018) mengungkapkan bahwa kemampuan berpikir kreatif harus dilakukan dalam waktu yang relatif lama dan secara kontinu. Selain itu, potensi kemampuan berpikir kreatif setiap orang berbedabeda baik dari sudut pandang maupun dari karakteristik berpikir keatif yang dimilikinya. Kemampuan berpikir kreatif seseorang dipengaruhi oleh karakteristik pribadi, karakter permasalahan, dan sudut pandang seseorang.

Model PBLFC lebih mampu mengembangkan kemampuan berpikir kreatif siswa dibandingkan dengan model PTFC dan DI. Namun, terdapat beberapa hal yang menyebabkan masih banyak siswa pada kelompok PBLFC, PTFC, dan DI yang belum mampu mencapai kemampuan berpikir kreatif pada kategori sangat tinggi.

Pertama, pada awal pertemuan siswa belum mampu menyesuaikan diri dengan model PBLFC dan PTFC karena siswa masih terbiasa dengan model pembelajaran yang diterapkan di sekolah. Kedua, siswa juga belum terbiasa dengan LKS PBLFC yang disediakan sehingga menghabiskan banyak waktu untuk menuntun mereka dalam mengerjakan LKS tersebut.

Ketiga, penggunaan web untuk model kelas terbalik juga menjadi kendala dikarenakan sebelumnya siswa belum pernah menggunakan web tersebut dan masih belum terbiasa akan pembelajaran kelas terbalik ini. Hal ini menyebabkan banyak siswa yang telat menerima informasi untuk pengerjain kuis di web tersebut dan masih kebingungan dalam menggunakan web tersebut.

Keempat, pada saat melakukan eksperimen di dalam kelas secara 
berkelompok, ada beberapa anggota kelompok yang hanya berdiam saja dan mengandalkan temannya untuk melakukan eksperimen sehingga siswa yang tidak ikut melakukan eksperimen tidak mengeskplor pengetahuannya secara aktif.

Upaya yang dilakukan untuk mengatasi kendala tersebut antara lain. Pertama, menekankan kepada siswa bahwa aktivitas siswa selama kegiatan pembelajaran diobservasi baik kerja kelompok, praktikum, dan lain-lain. Hal ini dilakukan agar siswa dalam proses pembelajaran dapat memahami dan melaksanakan proses pembelajaran secara optimal.

Kedua, sebelum memberikan LKS kepada siswa, terlebih dahulu guru menyampaikan petunjuk pengerjaan dengan baik agar seluruh komponen dalam LKS dapat diselesaikan dengan baik oleh siswanya, mengingat siswa belum terbiasa dengan model pembelajaran yang mengacu pada LKS. Ketiga, sebelum mempergunakan web edmodo tersebut, sebaiknya siswa diberikan petunjuk secara detail terkait penggunaan web itu dalam proses pembelajaran nanti. Selain itu, sebelum meng-upload kuis hendaknya guru memberikan informasi kepada siswa agar tidak ada siswa yang telat untuk mengerjakan kuis.

Keempat, mengoptimalkan peran guru untuk memberikan bimbingan kepada masing-masing kelompok sehingga kegiatan pembelajaran berjalan optimal. Ditekankan kepada siswa dalam pelaksanaan eksperimen, siswa akan diobservasi sehingga tidak ada siswa yang hanya mengandalkan temannya untuk melakukan eksperimen.

Temuan penelitian ini memiliki implikasi sebagai berikut. Pertama, ratarata kemampuan berpikir kreatif siswa yang belajar dengan menggunakan model PBLFC berbeda dengan rata-rata kemampuan berpikir kreatif siswa yang belajar dengan menggunakan model PTFC dan model DI. Perbedaan rata-rata kemampuan berpikir kreatif antartiga kelompok menunjukkan bahwa nilai rata-rata kemampuan berpikir kreatif pada kelas yang menggunakan PBLFC lebih tinggi dibandingkan dengan kelas menggunakan yang PTFC dan DI.

Kedua, pembelajaran dengan menggunakan PBLFC relatif lebih baik untuk meningkatkan kemampuan berpikir kreatif dibandingkan dengan menggunakan PTFC dan DI. Kerelatifan unggulnya kemampuan berpikir kreatif siswa pada kelas yang menggunakan PBLFC merupakan dampak dari LKS PBLFC yang membiasakan siswa berpikir kreatif untuk memberikan solusi pemecahan masalah. Hal ini akan membawa implikasi bahwa pembelajaran dengan menggunakan model membiasakan siswa dalam berpikir kreatif, di mana berpikir kreatif ini merupakan salah satu tuntutan untuk generasi muda pada abad ke-21. Sebaliknya siswa yang belajar dengan menggunakan PTFC dan DI tidak merasakan pengalaman belajar yang membiasakan mereka untuk berpikir kreatif.

\section{SIMPULAN}

Berdasarkan hasil penelitian dan pembahasan dapat disimpulkan bahwa terdapat perbedaan kemampuan berpikir kreatif antara siswa yang belajar menggunakan model PBLFC, model PTFC, dan model DI dalam pembelajaran fisika kelas X di SMA Negeri 1. Kelompok siswa yang belajar dengan model PBLFC memiliki kemampuan berpikir kreatif secara signifikan lebih tinggi dibandingkan dengan kelompok siswa yang belajar dengan model PTFC. Kelompok siswa yang belajar dengan model PBLFC memiliki kemampuan berpikir kreatif secara signifikan lebih tinggi dibandingkan dengan 
kelompok siswa yang belajar dengan model DI. Kelompok siswa yang belajar dengan model PTFC memiliki kemampuan berpikir kreatif secara signifikan lebih tinggi dibandingkan dengan kelompok siswa yang belajar dengan model DI.

\section{DAFTAR PUSTAKA}

Cakiroglu, U., \& Ozturk. M. (2017). Flipped classroom with problem based activities: explore self-regulated learning in a programming languange course. Educational Technology \& Society, 20(1), 337-349. Diunduh dari https://creativecommons. org/liceses/ by-nc-nd/3.0/.

Chis, A. E., Moldovan, A.-N., Murphy, L., Pathak, P., \& Muntean, C. H. (2018). Investigating flipped classroom and problem-based learning in a programming module for computing conversion course. Educational Technology \& Society, 21(4), 232-247. Diunduh dari https:// creativecommons. org/licenses/by-nc-nd/3.0/.

Djidu, H., \& Jailani. (2018). Pengembangan model pembelajaran kalkulus berbasis masalah. Jurnal Kependidikan, 2(1), 68-84. Diunduh dari https:// journal.uny.ac.id/index.php/jk/article/ view/12689/pdf.

Geminiawan, I. M. D. D. (2018). Pengaruh pembelajaran inkuiri terbimbing terhadap kemampuan berpikir kreatif dan sikap ilmiah siswa kelas XI MIPA SMA Negeri 3 Singaraja (Skripsi tidak diterbitkan). Fakultas Matematika dan Ilmu Pengetahuan Alam, Universitas Pendidikan Ganesha, Bali.

Hasanah, E., Darmawan, D., \& Nanang. (2019). Pengaruh penggunaan media pembelajaran articulate dalam metode problem-based learning (PBL) terhadap peningkatan kemampuan berpikir kreatif siswa. JTEP-Jurnal Teknologi
Pendidikan dan Pembelajaran, 4(1), 826-838. Diunduh dari https://journal. institutpendidikan.ac.id/index.php/ tekp/article/view/503.

Hidayah, R., Salimi, M., \& Susiani, T. S. (2017). Critical thinking skill: Konsep dan indikator penilaian. Jurnal Taman Cendekia, 1(2), 127-133. Diunduh dari http://jurnal. ustjogja.ac.id/index.php/ tamancendekia/article/view/1945.

Menteri Perindustrian. (2018, Maret). Making Indonesia 4.0: Strategi RI masuki revolusi rndustri ke-4. Diunduh dari http://www.kemenperin.go.id/ artikel/18967/Making-Indonesia-4.0:Strategi-RI-Masuki-Revolusi-Industri$\mathrm{Ke}-4$.

Presiden Republik Indonesia. (2003). Undang-Undang Republik Indonesia Nomor 20 Tahun 2003 tentang Sistem Pendidikan Nasional. Jakarta.

Reynawati, A., \& Purnomo, T. (2018). Penerapan model problem-based learning pada materi pencemaran lingkungan untuk melatihkan keterampilan berpikir kreatif siswa. Jurnal Pendidikan Sains (PenSa), 6(2), 325-329. Diunduh dari http:// jurnalmahasiswa.unesa.ac.id/index. php/pensa/index.

Rizal, M., Amrita, A., \& Darsono. (2018). Development of student worksheet problem-based learning model to increase higher order thinking skills. IOSR International Journal of Research \& Method in Education (IOSR-JRME), 8(2), 59-65. Diunduh dari www.iosrjournals.org.

Septiana, K. G., \& Ikhsan, J. (2017). Pengaruh penerapan multiple intelligences dengan model $P B L$ terhadap pemahaman konsep dan kemampuan berpikir kreatif. Jurnal Edukasi Matematika dan Sains (JEMS), 5(1), 43-52. Diunduh dari 
http://e-journal.unipma.ac.id/indec. $\mathrm{php} / \mathrm{JEMS}$.

Sihaloho, R. R., Sahyar, \& Ginting, E. M. (2017). The effect of problem-based learning (PBL) model toward student's creative thinking and problem solving ability in senior high school. IOSR Journal of Research \& Method in Education (IOSR-JRME), 7(4), 11-18. Dari: www.iosrjournals.org.

Sirait, A. R., Sinaga, B., \& Mulyono. (2018). Analysis difficulty of mathematical creative thinking ability reviewed from learning styles through problem-based learning. Advances in Social Sciences Research Journal, 5(10), 395-404. Diunduh dari www. iosrjournals.org.
Trianggo, M. M., \& Yuanita, S. (2018) Karakteristik keterampilan berpikir kreatif dalam pemecahan masalah fisika berdasarkan gender. Jurnal Pendidikan Fisika dan Keilmuan (JPFK), 4(2), 98-106. Diunduh dari http://e-journal.unipma.ac.id/index. $\mathrm{php} / \mathrm{JPFK}$.

Triyono, Senam, Jumadi, \& Wilujeng, I. (2017). Pengaruh pembelajaran IPA berbasis creative problem solving terhadap kreativitas SMP. Jurnal Kependidikan, 1(2), 214-226. Diunduh dari https://journal.uny.ac.id/index. php/jk/article/view/9429/pdf.

Wakil Menteri Pendidikan dan Kebudayaan. (2014). Konsep dan implementasi kurikulum 2013. Jakarta: Kemendikbud. 